\title{
Paracrine GABA and insulin regulate pancreatic alpha cell proliferation in a mouse model of type 1 diabetes
}

\author{
Allen L. Feng ${ }^{1} \cdot$ Yun-Yan Xiang ${ }^{1} \cdot$ Le Gui $^{2} \cdot$ Gesthika Kaltsidis $^{2} \cdot$ Qingping Feng $^{2}$ • \\ Wei-Yang $\mathrm{Lu}^{1,2}$
}

Received: 1 December 2016 / Accepted: 8 February 2017 / Published online: 9 March 2017

(C) Springer-Verlag Berlin Heidelberg 2017

\begin{abstract}
Aims/hypothesis This study aimed to elucidate the mechanism of increased proliferation of alpha cells in recent-onset type 1 diabetes. Pancreatic beta cells express GAD and produce $\gamma$ aminobutyric acid (GABA), which inhibits alpha cell secretion of glucagon. We explored the roles of GABA in alpha cell proliferation in conditions corresponding to type 1 diabetes in a mouse model and in vitro.

Methods Type 1 diabetes was induced by injecting the mice with streptozotocin (STZ). Some of the STZ-injected mice were treated with GABA (10 mg/kg daily) for 12 days. Isolated pancreatic islets were treated with STZ or STZ together with GABA for 2 days. The effects of GABA treatment on STZ-induced alpha cell proliferation in vivo and in vitro were assessed. The effect of muscimol, a GABA receptor agonist, on $\alpha \mathrm{TC} 1-6$ cell proliferation was also examined.

Results STZ injection substantially decreased levels of GAD, GABA and insulin in pancreatic beta cells $12 \mathrm{~h}$ after injection; this was followed by an upsurge of phosphorylated mechanistic target of rapamycin (p-mTOR) in the alpha cells at day 1 , and a significant increase in alpha cell mass at day 3. Treating STZ-
\end{abstract}

Allen L. Feng and Yun-Yan Xiang contributed equally to this study.

Electronic supplementary material The online version of this article (doi:10.1007/s00125-017-4239-x) contains peer-reviewed but unedited supplementary material, which is available to authorised users.

Wei-Yang Lu

wlu53@uwo.ca

1 Robarts Research Institute, Rome: 7240, University of Western Ontario, 1151 Richmond Street North, London, ON N6A 5B7, Canada

2 Department of Physiology and Pharmacology, Schulich School of Medicine and Dentistry, University of Western Ontario, London, ON, Canada injected mice with GABA largely restored the immunodetectable levels of insulin and GAD in the beta cells and significantly decreased the number of aldehyde dehydrogenase 1 family, member A3 (ALDH1a3)-positive cells, alpha cell mass and hyperglucagonaemia. STZ treatment also increased alpha cell proliferation in isolated islets, which was reversed by co-treatment with GABA. Muscimol, together with insulin, significantly lowered the level of cytosolic $\mathrm{Ca}^{2+}$ and $\mathrm{p}$ mTOR, and decreased the proliferation rate of $\alpha \mathrm{TC} 1-6$ cells. Conclusions/interpretation GABA signalling critically controls the alpha cell population in pancreatic islets. Low intraislet GABA may contribute to alpha cell hyperplasia in early type 1 diabetes.

Keywords Alpha cell $\cdot$ Beta cell $\cdot$ Diabetes $\cdot$ GAD . Glucagon · Insulin · Proliferation · Streptozotocin · Transdifferentiation $\cdot \gamma$-Aminobutyric acid

$\begin{array}{ll}\begin{array}{ll}\text { Abbreviations } \\ \alpha 1 \mathrm{GABA}_{\mathrm{A}} \mathrm{Rs}\end{array} & \alpha 1 \text { subunit of type A GABA receptor } \\ \alpha 4 \mathrm{GABA} \mathrm{A}_{\mathrm{A}} \mathrm{A} & \alpha 4 \text { subunit of type A GABA receptor } \\ \text { ALDH1a3 } & \text { Aldehyde dehydrogenase } 1 \text { family, member A3 } \\ \text { GABA } & \gamma \text {-Aminobutyric acid } \\ \text { GABA }_{\mathrm{A}} \mathrm{R} & \text { Type A GABA receptor } \\ \text { GLP-1 } & \text { Glucagon-like peptide } 1 \\ \text { mTOR } & \text { Mechanistic target of rapamycin } \\ \text { STZ } & \text { Streptozotocin }\end{array}$

\section{Introduction}

Pancreatic alpha cells are located close to and operate cooperatively with beta cells in the islets of Langerhans. Under physiological conditions, these two types of cell secrete the 
'counterregulatory' hormones glucagon and insulin, respectively, ensuring normoglycaemia. Type 1 diabetes mellitus is caused by autoimmune destruction of the beta cells $[1,2]$. In patients [3] with and animal models [4-7] of recent-onset type 1 diabetes, there is a significant increase in the number of alpha cells in the islets. However, the mechanisms underlying this increase in alpha cells in recent-onset type 1 diabetes remain unclear [8].

The increase in alpha cells in recent-onset type 1 diabetes may result from a paucity of paracrine factors released from the beta cells. Early studies showed that beta cells produce $\gamma$ aminobutyric acid (GABA) via the activity of $\operatorname{GAD}[9,10]$, which is localised around GABA-containing microvesicles [11]. In addition, type A GABA receptors $\left(\mathrm{GABA}_{\mathrm{A}} \mathrm{Rs}\right)$, a class of chloride channels, are expressed in both beta and alpha cells [12-15]. Due to the disparity in expression levels of chloride-intruding and chloride-extruding transporters, the intracellular chloride concentration is high in beta cells but low in alpha cells $[16,17]$. Therefore stimulation of $\mathrm{GABA}_{\mathrm{A}} \mathrm{Rs}$ in the beta cells causes chloride efflux and membrane depolarisation, increasing $\mathrm{Ca}^{2+}$ entry and insulin secretion [18-20], whereas activation of $\mathrm{GABA}_{\mathrm{A}} \mathrm{Rs}$ in alpha cells results in chloride influx and membrane hyperpolarisation, decreasing $\mathrm{Ca}^{2+}$ entry and glucagon release [12, 21].

Activation of $\mathrm{GABA}_{\mathrm{A}}$ Rs inhibits neural stem cell proliferation [22] and promotes neuroprogenitor differentiation [23] through the $\mathrm{Ca}^{2+}$-dependent kinase mechanistic target of rapamycin (mTOR) [24]. Moreover, GABA facilitates pancreatic beta cell generation [14] and insulin regulates beta cell proliferation via the mTOR signalling pathway $[7,25,26]$. This study sought to investigate the roles of intraislet GABA and insulin in regulating alpha cell proliferation, as well as the attendant signalling mechanism(s), in recent-onset type 1 diabetes.

\section{Methods}

Type 1 diabetes model, animal groups and treatments Male C57BL/6 mice (8-10 weeks old; Charles River Laboratories, Senneville, QC, Canada) were used in this study, and they were handled in line with the Guide for the care and use of laboratory animals, published by the U.S. National Institutes of Health (NIH publication no. 85-23, revised 1996). In the first batch of experiments, conditions of type 1 diabetes were induced in 38 mice by a single i.p. injection of streptozotocin $(\mathrm{STZ} ; 150 \mathrm{mg} / \mathrm{kg}$ in $0.2 \mathrm{ml}$ saline [154 mmol/1 NaCl]). Another 12 mice injected with saline alone served as controls. Mice were euthanised at $2 \mathrm{~h}$ $(n=5), 6 \mathrm{~h}(n=5), 12 \mathrm{~h}(n=6), 1$ day $(n=5), 2$ days $(n=6), 3$ days $(n=5)$ and 2 weeks $(n=6)$ after treatment.

The second batch of experiments employed four groups of mice. The control group $(n=6)$ received $0.2 \mathrm{ml}$ saline daily for 12 days. The mice in the STZ group $(n=10)$ were treated daily with saline for the first 4 days, a single dose of STZ $(150 \mathrm{mg} / \mathrm{kg}$, i.p.) on day 5 , and saline daily for another 7 days. The GABA group mice $(n=8)$ were treated with GABA $(10 \mathrm{mg} / \mathrm{kg}$, i.p.) daily for 12 days. Finally, the mice in the STZ + GABA group $(n=8)$ were treated with GABA $(10 \mathrm{mg} / \mathrm{kg})$ daily for the first 4 days and a single dose of STZ $(150 \mathrm{mg} / \mathrm{kg})$ on day 5 , followed by GABA daily for another 7 days. All mice were euthanised on day 19, and pancreatic tissues were collected for analysis.

Blood glucose and glucagon assays Two weeks after the STZ injection, mice in the second batch of experiments were fasted for $16 \mathrm{~h}$ before tail blood glucose was measured using a glucose meter (OneTouch Ultra2, LifeScan, Wayne, PA, USA). Blood was then collected by cardiac puncture under anaesthesia to obtain serum. Serum glucagon was measured using the Glucagon EIA Kit (Sigma-Aldrich Canada, Oakville, ON Canada), following the manufacturer's instructions.

Immunohistochemistry, image analysis and endocrine cell mass measurement As previously reported [20], pancreatic tissues were serially cut into $5 \mu \mathrm{m}$ sections at $50 \mu \mathrm{m}$ intervals. After serum blocking, tissue sections were incubated at $4^{\circ} \mathrm{C}$ overnight with specific primary antibodies against insulin, glucagon-like peptide 1 (GLP-1), Ki67 (Abcam, Toronto, ON, Canada), glucagon, GAD (Sigma-Aldrich, G5163), the $\alpha 1\left(\alpha 1 G_{A B A} R\right)$ and $\alpha 4\left(\alpha 4 G A B A_{A} R\right)$ subunits of $\mathrm{GABA}_{\mathrm{A}} \mathrm{R}$, aldehyde dehydrogenase 1 family, member $\mathrm{A} 3$ (ALDH1a3; Novus Biologicals, Oakville, ON, Canada), pmTOR) and KIT proto-oncogene receptor tyrosine kinase (cKit; R\&D Systems, Minneapolis, MN, USA). After primary antibody fostering, sections were simmered with Cy3- or FITC-conjugated secondary antibody. Omission of primary antibody was used as a negative control. Nuclei were stained with DAPI $(5 \mu \mathrm{g} / \mathrm{ml})$. Confocal microscopic images were taken from each section.

Images were analysed using Image-J (https://imagej.nih. gov/ij/) as previously described $[20,27]$. To assess each of the immunostained proteins, we analysed between 18 and 68 islets in pancreatic slices prepared from five or six mice in each group. The area of individual islets and the total area of glucagon-positive or insulin-positive cells in the islet were quantified as a measure of alpha and beta cell mass, respectively. As previously described [28], the mass of alpha cells and beta cells was calculated by dividing the total area of glucagon- and insulin-expressing cells, respectively, by the total pancreatic area and then multiplying by the pancreatic weight. The averaged intensity of protein immunofluorescence in individual islets was reported in arbitrary units. Mander's coefficient of co-localisation of stained proteins was evaluated using the intensity correlation analysis [29]. 
Pancreatic islet isolation, culture and treatment Pancreatic islets were isolated from C57BL/6 mice $(n=8)$ using liberase RI digestion as previously described [28] with modifications. Briefly, under a surgical microscope, the major duodenal papilla and common hepatic duct were ligated, while a $30 \mathrm{G}$ needle attached to a $10 \mathrm{ml}$ syringe was cannulated into the common bile duct. The pancreas was perfused with $50 \mu \mathrm{g} / \mathrm{ml}$ liberase RI $(5.0 \mathrm{ml}$; Roche Diagnostics, Laval, QC, Canada) and then carefully removed. The pancreas was digested at $37^{\circ} \mathrm{C}$ for $16-18 \mathrm{~min}$ with vigorous shaking every $4 \mathrm{~min}$. The digested samples were filtered through a $0.5 \mathrm{~mm}$ wire mesh and centrifuged at $400 \mathrm{~g}$ for $2 \mathrm{~min}$ at $4^{\circ} \mathrm{C}$. The pellets were resuspended in $10 \mathrm{ml}$ RPMI1640 with $10 \%$ serum, $2.0 \mathrm{mmol} / 1 \mathrm{~L}$-glutamine 100 units $/ \mathrm{ml}$ penicillin and $100 \mathrm{mg} / \mathrm{ml} \mathrm{streptomycin.} \mathrm{The} \mathrm{isolated} \mathrm{islets} \mathrm{were} \mathrm{hand-}$ picked under a microscope and cultured overnight with the same medium in an atmosphere of $95 \%$ air and $5 \% \mathrm{CO}_{2}$ at $37^{\circ} \mathrm{C}$. Islets were separated into groups (16-20 per group) and treated with either $2.0 \mathrm{mmol} / 1 \mathrm{STZ}, 1.0 \mathrm{mmol} / 1 \mathrm{GABA}$ or $2.0 \mathrm{mmol} / 1 \mathrm{STZ}+1.0 \mathrm{mmol} / 1 \mathrm{GABA}$ for $48 \mathrm{~h}$. Test islets were fixed in $4 \%$ paraformaldehyde and then triple-stained for insulin, glucagon and DAPI. Images of the stained islets were taken using confocal microscopy.

Experiments on cultured $\alpha$ TC1-6 cells Mouse pancreatic alpha cell line $\alpha \mathrm{TC} 1-6$ cells [30] were cultured in regular dishes for immunoblotting immunostaining or growth assay. The cells in each group were treated with insulin (10 nmol/1), the $\mathrm{GABA}_{\mathrm{A}} \mathrm{R}$ agonist muscimol $(50 \mu \mathrm{mol} / \mathrm{l})$ and rapamycin ( $1.0 \mu \mathrm{mol} / \mathrm{l})$ alone or in combination. The concentration of muscimol used for the group tests was determined by doseresponse analyses (see electronic supplementary material [ESM] Fig. 1).

Using a Countess Automated Cell Counter kit (Life Technologies, Burlington, ON, Canada), the number of $\alpha \mathrm{TC} 1-6$ cells was analysed $6 \mathrm{~h}$ and $30 \mathrm{~h}$ after seeding. Cell lysates were immunoblotted using the following primary antibodies: anti-p-Ser2448 of mTOR and anti-mTOR (Cell Signaling Technology, Danvers, MA, USA; catalogue nos 2971 and 2972) and anti- $\beta$-actin (Sigma-Aldrich). Blot band densities were calculated using the Quantity One program (Bio-Rad, www.bio-rad.com/en-uk/product/quantity-one-1d-analysis-software) and normalised to that of $\beta$-actin. Immunocytochemistry was performed as previously described [27, 31, 32]. Briefly, $\alpha$ TC1-6 cells were incubated with rabbit anti-Ki67 (ab15580; Abcam), rabbit anti$\mathrm{GABA}_{\mathrm{A}} \mathrm{R} \alpha 1$ (no. 06-868; Millipore, Peel, ON, Canada) or anti-p-Ser2448 of mTOR (sc-101,738; Santa Cruz Biotechnology, Dallas, TX, USA) at $4{ }^{\circ} \mathrm{C}$ overnight and subsequently with $\mathrm{Cy} 3$ - or FITC-conjugated secondary antibodies at room temperature for $1 \mathrm{~h}$. Immunofluorescence was viewed under a Zeiss LSM 510 confocal microscope, and images acquisition was performed using AxioVision software
(Zeiss Canada, North York, ON, Canada). Following a previously described procedure [33], cytosolic $\mathrm{Ca}^{2+}$ levels in $\alpha$ TC1-6 cells were recorded by dual-wavelength fura- 2 microfluorometry and analysed using ImageMaster software (Photon Technology International, Birmingham, NJ, USA).

Statistical analysis Statistical analysis was performed using one-way ANOVA followed by the Student-Newman-Keuls test for multigroup comparisons. The unpaired Student's $t$ test was used for comparing data between two groups. Data were expressed as mean $\pm \mathrm{SD}$. A $p$ value $<0.05$ was considered statistically significant.

\section{Results}

STZ injection caused sequential changes in GAD and insulin in beta cells, mTOR activity in alpha cells and alpha cell mass We first examined the immunofluorescence levels of GAD and $\mathrm{GABA}_{\mathrm{A}} \mathrm{R}$ subunits, mTOR activity and beta and alpha cell mass at different time points before (control) and after STZ injection. High levels of GAD65/67 immunofluorescence (Fig. 1a) and GABA (not shown) were detected in insulin-positive beta cells in control mice. GAD immunoreactivity significantly declined $12 \mathrm{~h}$ after STZ injection (Fig. 1a, b), and this was followed by a significant drop in the number of insulin-positive beta cells $24 \mathrm{~h}$ after STZ. As a control, GAD immunoreactivity in the adrenal medulla of STZ-treated mice was comparable to that of control mice (not shown). Two weeks after STZ injection, the immunofluorescence of GAD and insulin had largely faded away (Fig. 1a, b), although there were a few GAD-positive cells scattered in the islets (Fig. 1a). Immunofluorescence of the $\alpha 1$ and $\beta 2 / 3$ subunits of $\mathrm{GABA}_{\mathrm{A}} \mathrm{R}$ was demonstrated in beta cells, and this declined in the same temporal order as that of GAD after STZ treatment (ESM Fig. 2). The immunoreactivity of $\alpha 4 \mathrm{GABA}_{\mathrm{A}} \mathrm{Rs}$ was detected in both the alpha and beta cells of control mice (Fig. 1c). $\alpha 4 \mathrm{GABA}_{\mathrm{A}} \mathrm{R}$ immunoreactivity declined significantly in beta cells $12 \mathrm{~h}$ after STZ injection (Fig. 1b) but stayed at a high level in alpha cells 2 days after STZ injection (Fig. 1c).

In control pancreases, immunoreactivity of p-mTOR (active mTOR) was mainly associated with insulin-positive beta cells (Fig. 2b) but marginally correlated with glucagonpositive alpha cells (Fig. 2c, d). One day after injection, however, p-mTOR immunoreactivity primarily co-localised with alpha cells (Fig. 2c, d).

The alpha cell mass in control pancreases was $0.12 \pm 0.03 \mathrm{mg} / \mathrm{g}$ (Fig. 3a, b), whereas the beta cell mass was $1.2 \pm 0.12 \mathrm{mg} / \mathrm{g}$ (Fig. $3 \mathrm{a}, \mathrm{c}$ ). The beta cell mass fell significantly, to $0.14 \pm 0.04 \mathrm{mg} / \mathrm{g}, 2$ days after STZ injection, and partially recovered, to $0.26 \pm 0.14 \mathrm{mg} / \mathrm{g}, 2$ weeks after STZ had been given (Fig. 3c). In contrast, the mass of alpha 

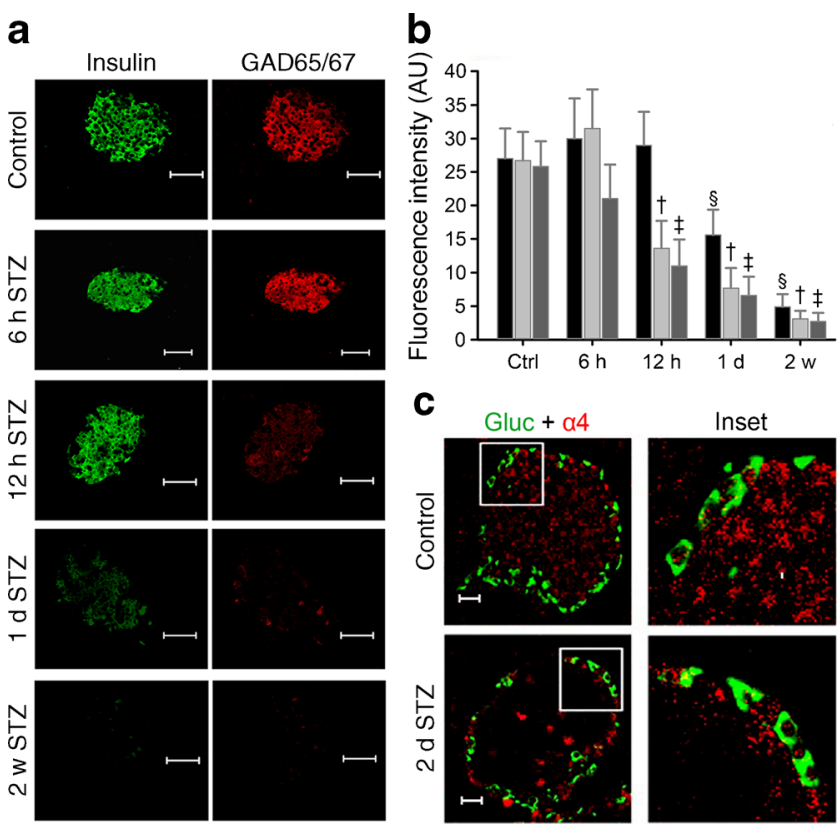

Fig. 1 STZ decreased the immunoreactivity of GAD and $G A B A_{A} R$ s in beta cells but did not change the immunoreactivity of $\mathrm{GABA}_{\mathrm{A}} \mathrm{Rs}$ in alpha cells. (a) Immunostaining of insulin and GAD65/67 in the pancreatic islets of a control mouse and STZ-treated mice at different times after STZ injection. Scale bars, $50 \mu \mathrm{m}$. (b) Immunofluorescence intensity of insulin, GAD65/67 and $\alpha 4 \mathrm{GABA}_{\mathrm{A}} \mathrm{Rs}$ in the islets of control mice and STZ-treated mice at different times after STZ injection ( ${ }^{\dagger} \mathrm{GAD}$, $\alpha 4 \mathrm{GABA}_{\mathrm{A}} \mathrm{R}, \S_{\text {insulin, compared with control, } p<0.01 ; n=22-25}$ samples at each time point). Black bars, insulin; light grey bars, GAD; dark grey bars, $\alpha 4 \mathrm{GABA}_{\mathrm{A}}$ Rs. (c) Double-staining of glucagon and $\alpha 4 \mathrm{GABA}_{\mathrm{A}} \mathrm{Rs}(\alpha 4)$ in control islet and islet of a STZ-treated mouse 2 days after treatment. Scale bars, $20 \mu \mathrm{m}$. AU, arbitrary units; Ctrl, control; d, day(s); Gluc, glucagon; w, weeks

cells significantly increased 3 days after STZ and reached $0.74 \pm 0.17 \mathrm{mg} / \mathrm{g} 2$ weeks after STZ injection (Fig. 3b).

Beta cells expressing Ki67, a cell proliferation marker [34], were frequently observed in the islets of control mice (ESM Fig. 3a), but few alpha cells expressed Ki67 (Fig. 3d). Notably, the number of Ki67-expressing alpha cells significantly increased 2 days after STZ administration (Fig. 3d, e), and the proportion of Ki67-positive alpha cells stayed significantly higher than those of controls even 2 weeks after STZ injection (Fig. 3d, e). Alpha cells also displayed high immunoreactivity for GLP-1; the proportion of GLP-1-positive cells significantly increased 2 days after STZ and was maintained 2 weeks after treatment (Fig. 3g). The proportion of Ki67positive beta cells also increased in islets 2 weeks after STZ administration, although it was not significantly different from control values (Fig. 3h, i).

GABA treatment reduced alpha cell hyperplasia and hyperglucagonaemia of STZ-treated mice Administration of GABA $(10 \mathrm{mg} / \mathrm{kg}$, daily) to the STZ-treated mice for 12 days restored intraislet GAD immunoreactivity (ESM Fig. 3b) in STZ-treated mice to a level comparable to that in
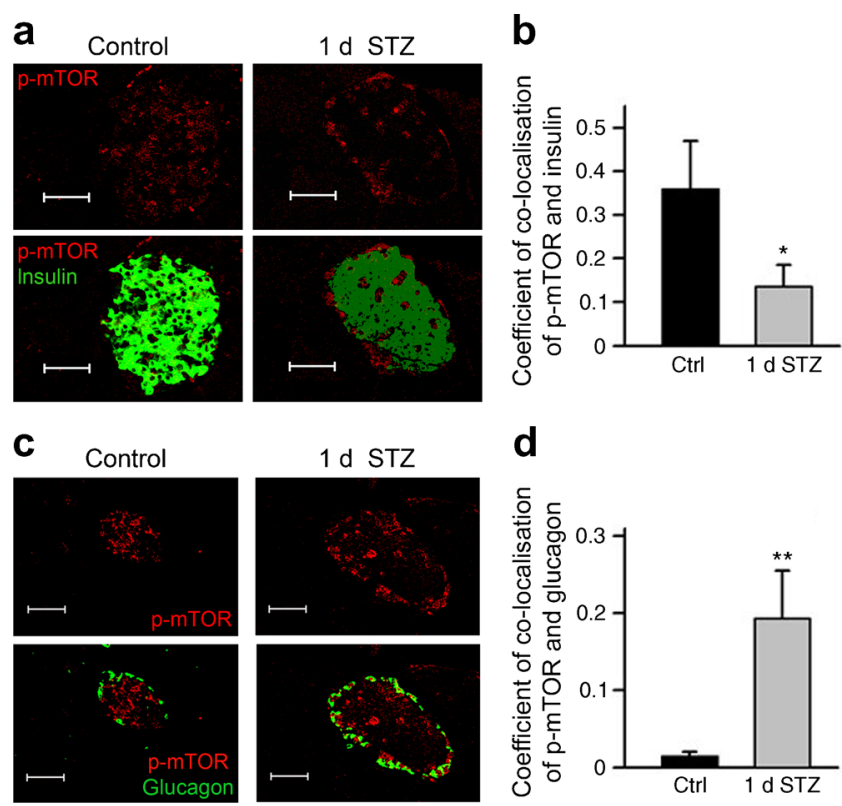

Fig. 2 mTOR activity increased in alpha cells after a drastic loss of beta cells. (a) p-mTOR immunofluorescence was associated with insulin-positive beta cells in control islets. Scale bars, $50 \mu \mathrm{m}$. One day after STZ treatment, the immunofluorescence of p-mTOR and insulin faded from most beta cells. (b) Coefficients of p-mTOR/insulin co-localisation in islets of control mice and STZ-treated mice 1 day after STZ injection (compared with control, ${ }^{*} p<0.05, n=18$ islets in each group). (c) $\mathrm{p}$ mTOR immunofluorescence was not associated with alpha cells in control islets, but appeared in most glucagon-positive alpha cells 1 day after STZ injection. Scale bars, $50 \mu \mathrm{m}$. (d) Coefficients of p-mTOR/glucagon co-localisation in islets of control mice and STZ-injected mice 1 day after STZ. (** $p<0.01$ compared with control; $n=18$ islets in each group). Ctrl, control; d, day(s)

control mice. Importantly, GABA treatment prevented the STZ-induced changes in alpha (Fig. 4a, b) and beta (Fig. 4a, c) cell mass.

As previously reported [35], STZ treatment greatly increased the expression of cKit, a progenitor cell marker [36], in most beta cells (not shown) and some alpha cells (ESM Fig. 4). Interestingly, a large population of ALDH1a3positive cells that represent phenotypically dedifferentiated and functionally failing beta cells [37] also appeared in the islets of STZ-treated mice (Fig. 4d, e), in which serum glucagon (Fig. 4f) and blood glucose (Fig. 4g) significantly increased. Remarkably, administering GABA to the STZtreated mice not only significantly decreased the number of pancreatic cKit-positive cells (ESM Fig. 4) and ALDH1a3positive cells (Fig. 4d, e), but also fundamentally lowered serum glucagon (Fig. 4f) and blood glucose (Fig. 4g) concentrations.

GABA prevented the STZ-induced alpha cell proliferation in isolated pancreatic islets Immunostaining assays identified both insulin-expressing beta cells and glucagonexpressing alpha cells in isolated pancreatic islets 

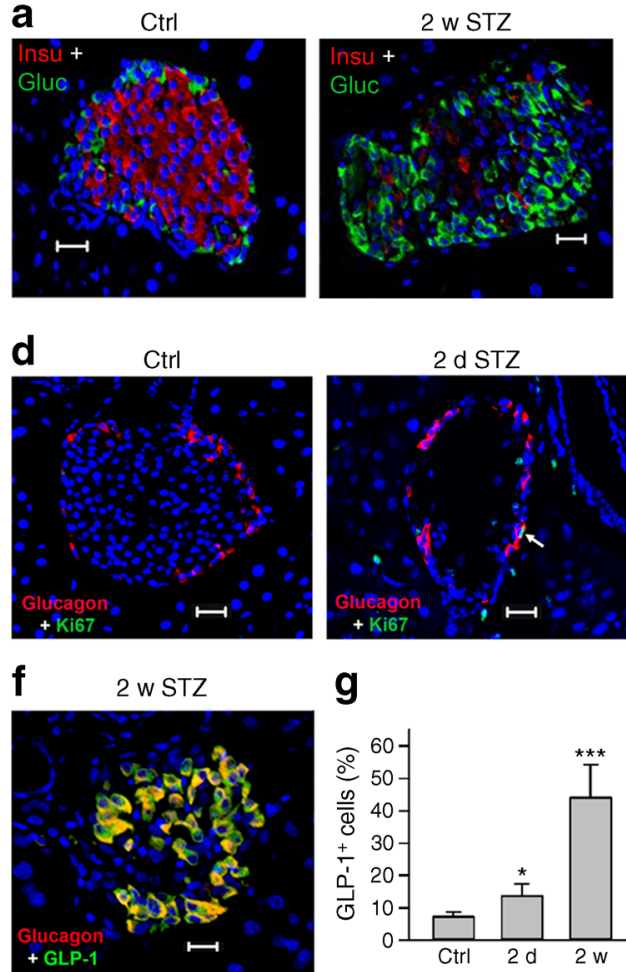

Fig. 3 STZ increased the proliferation of alpha cells expressing GLP-1. (a) Representative images of triple-staining of insulin, glucagon and DAPI in islets of control mouse and STZ-treated mouse 2 weeks after STZ injection. (b) Changes in alpha cell mass in control mice and STZinjected mice 2 days, 3 days and 2 weeks after treatment (compared with control, $* p<0.05, * * * p<0.001, n=46-59$ samples). (c) Beta cells mass in control mice and STZ-injected mice 2 days, 3 days and 2 weeks after treatment $(* * * p<0.001$ compared with control; $p<0.05$ compared between 2 days and 2 weeks; $n=47-68$ samples). (d) Representative images of triple-staining for glucagon, Ki67 and DAPI in the islets of control mouse and STZ-treated mouse 2 days and 2 weeks after STZ injection. (e) Percentage of Ki67-positive alpha cells in control and

(Fig. 5). The proportion of alpha cells to total cells in control islets (Fig. 5a) was $0.062 \pm 0.017$ ( $n=11$ islets). Forty-eight hours after adding $2.0 \mathrm{mmol} / 1 \mathrm{STZ}$ to culture media, the immunoreactivity of insulin (Fig. 5a, b) declined, while the proportion of alpha cells to total cells increased to $0.11 \pm 0.03$ ( $n=13$ islets; Fig. 5a, c). Remarkably, treating isolated islets with STZ and GABA $(1.0 \mathrm{mmol} / \mathrm{l})$ effectively restored the immunoreactivity of insulin (Fig. 5a, b) and significantly decreased the proportion of alpha cells to total cells to $0.061 \pm 0.014$ ( $n=10$ islets $)$ in single islets (Fig. 5a, c).

Activating $\mathrm{GABA}_{\mathbf{A}} \mathrm{Rs}$ decreased proliferation, cytosolic $\mathrm{Ca}^{2+}$ and mTOR activity of $\alpha$ TC1-6 cells Thirty hours after plating, the $\alpha \mathrm{TC} 1-6$ cells in the control dishes showed a doubling in the number of cells displaying active proliferation (Fig. 6a). The quantity of cells that had been treated with muscimol $(50 \mu \mathrm{mol} / \mathrm{l})$ was comparable to
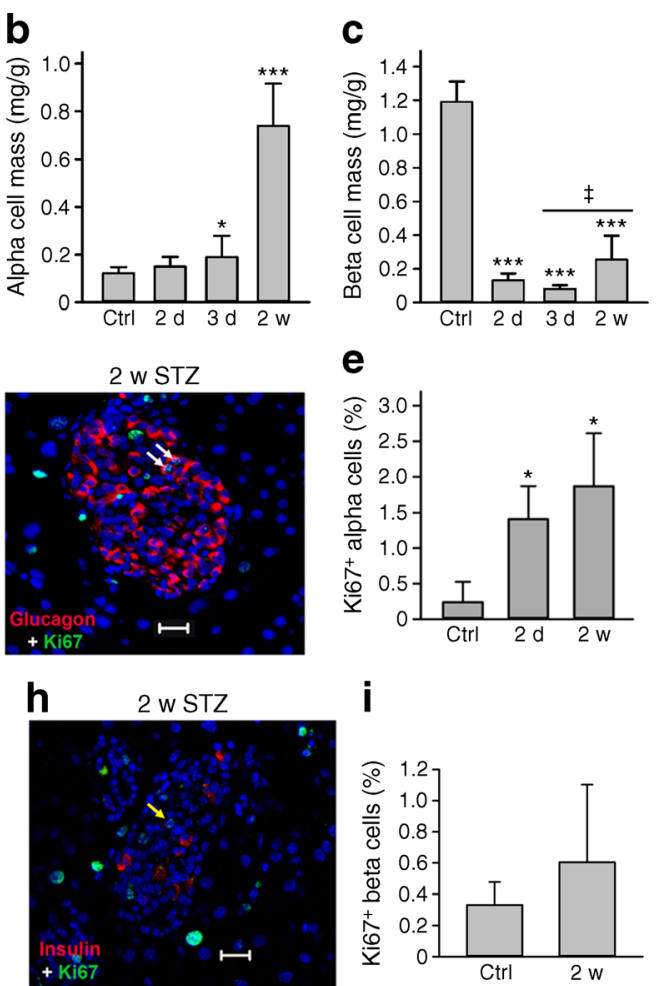

STZ-treated mice 2 days and 2 weeks after treatment $\left({ }^{*} p<0.05\right.$ compared with control; $n=20$ islets at each time point). (f) Triple-staining for glucagon, GLP-1 and DAPI in an islet of an STZ-treated mouse 2 weeks after treatment. (g) Fraction of GLP-1-positive alpha cells in control and STZ-treated mice 2 days and 2 weeks after treatment $(* p<0.05$, $* * * p<0.001$ compared with control; $n=19$ islets at each time point). (h) Triple-staining for insulin, Ki67 and DAPI in islet 2 weeks after STZ injection. (i) Measurement of Ki67-positive beta cells in control and STZinjected mice 2 weeks after treatment ( $n=18$ islets in each group). Scale bars, $20 \mu \mathrm{m}$. Ctrl, control; d, day(s); Gluc, glucagon; Insu, insulin; w, weeks

that of control cells, whereas the number of cells treated with insulin $(10 \mathrm{nmol} / \mathrm{l})$ increased significantly as reported [7]. Consistent with a previous report [12], insulin treatment increased $\alpha 1 \mathrm{GABA}_{\mathrm{A}} \mathrm{R}$ immunoreactivity in the cell membranes (not shown). Notably, the total number of cells treated with insulin + muscimol was not significantly different from the control (Fig. 6a). In cells treated with rapamycin $(1.0 \mu \mathrm{mol} / \mathrm{l})$, however, the insulin effect vanished, the proliferation rate declined (Fig. 6b) and the percentage of $\mathrm{Ki} 67^{+}$cells decreased (Fig. 6c). Notably, $30 \mathrm{~h}$ after combined treatment with insulin and muscimol, the population of $\mathrm{Ki}^{+} 7^{+}$cells also decreased to a level similar to that of rapamycin-treated group (Fig. 6c, d).

Immunoblotting assays of $\alpha \mathrm{TC} 1-6$ cells showed that insulin increased the phosphorylation level of both mTOR and P70S6K, a downstream kinase of mTOR, whereas insulin + muscimol significantly decreased p-mTOR (Fig. 7a, b) and pP70S6K (ESM Fig. 5a). In contrast, insulin alone or insulin + 

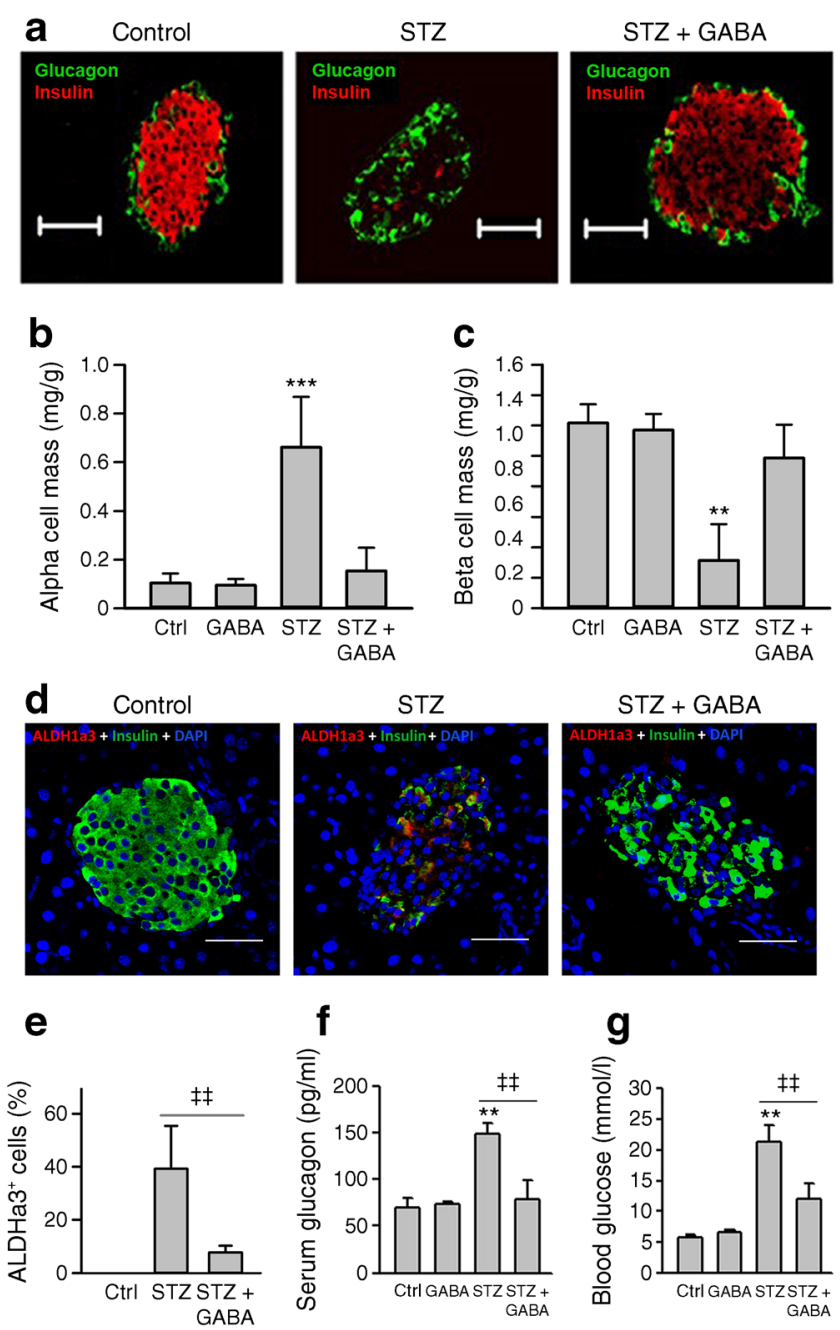

Fig. 4 GABA preserved beta cells but prevented alpha cell hyperplasia and hyperglucagonaemia in STZ-treated mice. (a) Representative images of insulin and glucagon immunofluorescence in control mice and mice treated with STZ or STZ + GABA 2 weeks after treatment. Scale bars, $50 \mu \mathrm{m}$. Alpha cell mass (b) and beta cell mass (c) of control mice and mice treated with STZ or STZ + GABA (**p $<0.01$, ***p $p<0.001$ compared with control; $n=45-51$ samples). (d) ALDH1a3-positive cells in islets of mice treated with saline (control), STZ or STZ + GABA 2 weeks after treatment. Scale bars, $40 \mu \mathrm{m}$. (e) ALDH1a3-positive cells in islets of control mice and mice treated with STZ or STZ + GABA 2 weeks after treatment (compared with the STZ + GABA group, $p<0.01 ; n=20$ islets in control group, and $n=13$ islets in STZ and $\mathrm{STZ}+$ GABA groups). Serum glucagon (f) and blood glucose (g) of control mice and mice treated with STZ or with STZ + GABA 2 weeks after treatment $(* * p<0.01$ compared with control; $p<0.01$ compared with STZ + GABA group; $n=6-7$ mice per group). Ctrl, control

muscimol affected the expression level of the tumour suppressor p53 (ESM Fig. 5b).

$\mathrm{Ca}^{2+}$-imaging analyses showed that bath perfusion of the insulin-treated $\alpha \mathrm{TC} 1-6$ cells with GABA $(1.0 \mathrm{mmol} / 1$ for $60 \mathrm{~s})$ significantly decreased intracellular $\mathrm{Ca}^{2+}$ (Fig. 7c,d), which returned to the basal level when GABA was washed out of the bath solution (Fig. 7c).
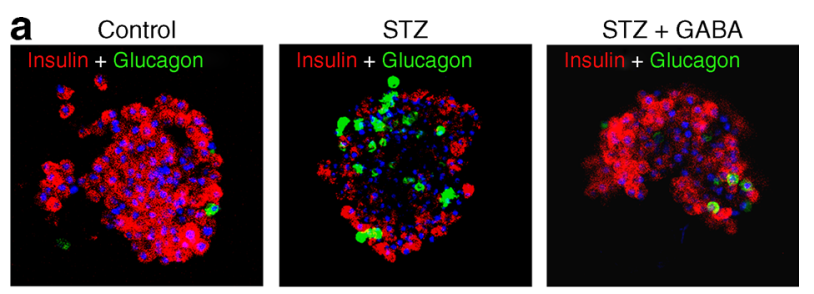
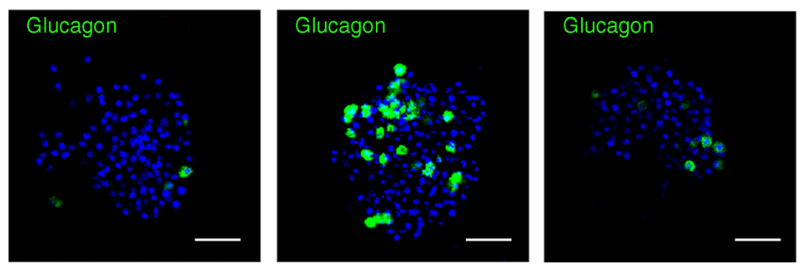

b
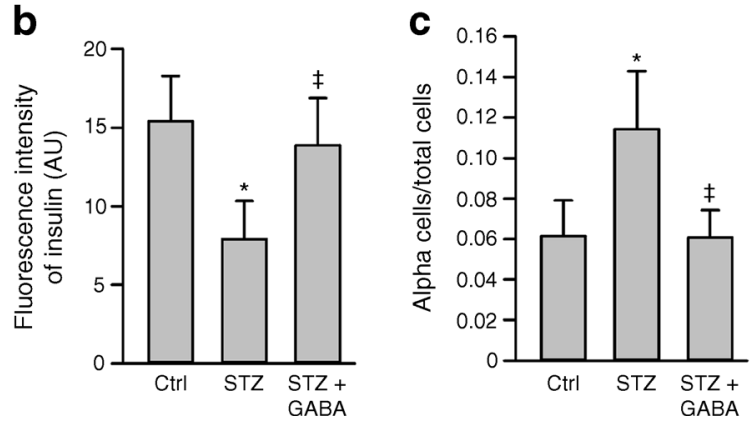

Fig. 5 GABA prevented STZ-induced alpha cell hyperplasia in isolated islets. (a) Upper row, immunostaining for glucagon, insulin and DAPI in islets isolated from a control mouse and mice treated with STZ or STZ + GABA. Lower row, STZ-induced alpha cell hyperplasia in isolated islets. Scale bars, $40 \mu \mathrm{m}$. (b) Fluorescence intensity of insulin within individual islets 2 days after treatment. (c) Ratio of glucagon-expressing cells in single islets. $(* p<0.05$ compared with control; $p<0.05$ compared with STZ). AU, arbitrary units; Ctrl, control

\section{Discussion}

GABA prevents STZ-induced alpha cell hyperplasia in vivo and in vitro Intraperitoneal injection of STZ is commonly used to induce the condition of diabetes in animal models of type 1 diabetes. Although it has been shown that STZ lowers intraislet GAD/GABA and results in alpha cell hyperplasia [4-7], the present study is the first to examine STZ-induced temporal changes in intraislet insulin and GAD, mTOR activity and alpha cell proliferation in the same model. Specifically, this study demonstrated that a drastic decline of GAD and insulin in beta cells was sequentially followed by elevated mTOR activity in alpha cells, increased Ki67positive/glucagon-positive-cells and an enlarged alpha cell mass. Such progressive changes in pancreatic islets suggest that the STZ-induced increased alpha cell proliferation may be initiated by a decline in intraislet GABA and insulin, as a result of beta cell injury.

Cells expressing high levels of cKit and/or ALDH1a3 display progenitor/stem cell-like features [36, 37]. After STZ treatment, the number of cKit-positive and ALDH1a3positive cells increased whereas the number of GAD- 

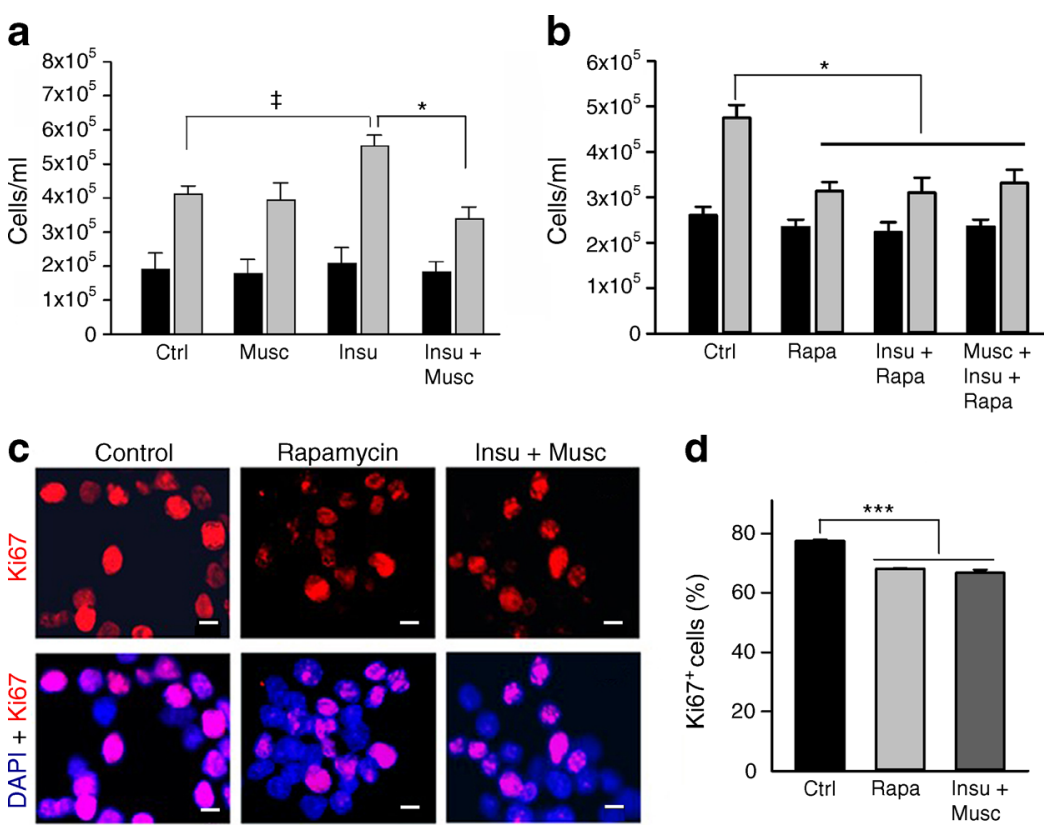

d

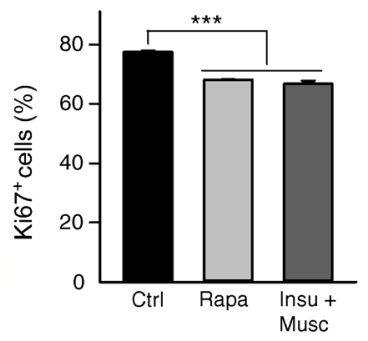

Fig. $6 \mathrm{GABA}_{\mathrm{A}} \mathrm{R}$ agonist suppression of $\alpha \mathrm{TC} 1-6$ cell proliferation. (a) $\alpha \mathrm{TC} 1-6$ cell numbers $6 \mathrm{~h}$ (black bars) and $30 \mathrm{~h}$ (light grey bars) after seeding (compared with control, $p<0.05$; comparing between insulin and insulin + muscimol treatments, $* p<0.05 ; n=3$ repeats). At $6 \mathrm{~h}$ after plating, the numbers $\alpha \mathrm{TC} 1-6$ cells are relatively equal across the groups. (b) Numbers of cells $6 \mathrm{~h}$ (black bars) and $30 \mathrm{~h}$ (light grey bars) after

positive/insulin-positive cells decreased in the islets, suggesting that some of the injured beta cells may 'dedifferentiate' [38] into a progenitor-like phenotype. Treatment with insulin
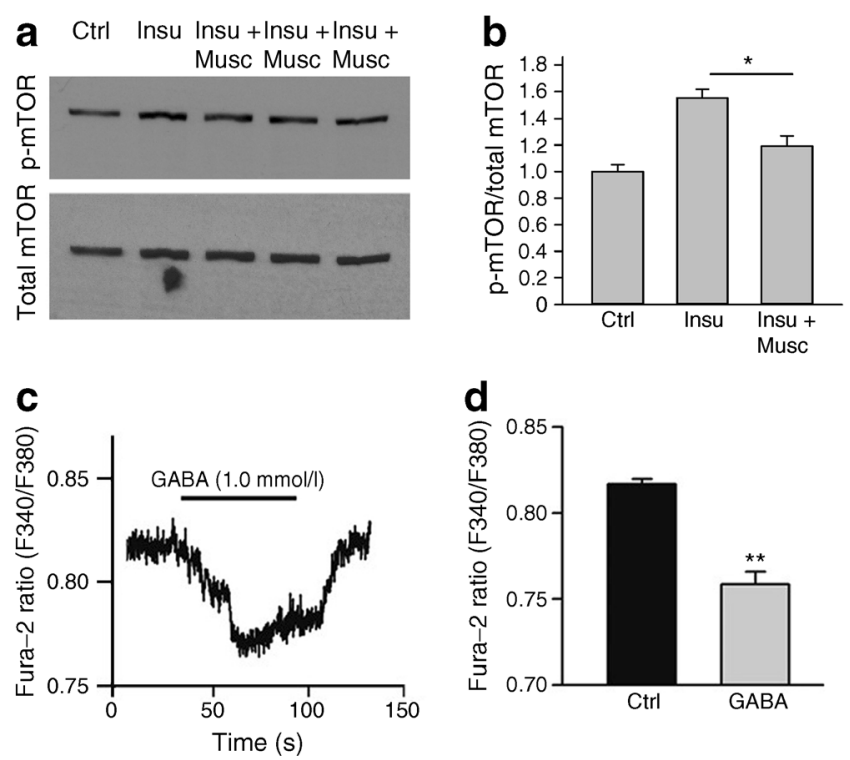

Fig. 7 Activating $\mathrm{GABA}_{\mathrm{A}} \mathrm{R}$ decreased $\mathrm{p}-\mathrm{mTOR}$ and $\mathrm{Ca}^{2+}$ concentration in $\alpha \mathrm{TC} 1-6$ cells. (a) Representative immunoblots of $\mathrm{p}-\mathrm{mTOR}$ and total mTOR in control $\alpha$ TC1- 6 cells and cells treated with insulin or insulin + muscimol. (b) p-mTOR/total mTOR in cells ( $n=4$ blots of three cultures; ${ }^{*} p<0.05, n=4$ repeats). (c) Change in fura- 2 ratio in response to GABA. (d) Plotted fura-2 ratios before and during GABA perfusion ( $n=7$ recordings; compared with control, ** $p<0.01$ ), Ctrl, control; Insu, insulin; Musc, muscimol seeding (comparing all groups with control, * $p<0.05 ; n=3$ repeats). (c) Ki67 and DAPI staining of $\alpha$ TC1-6 cells. Scale bars, $5 \mu \mathrm{m}$. (d) Effects of rapamycin or insulin + muscimol on the percentage of Ki67-positive $\alpha \mathrm{TC} 1-6$ cells (compared with control, $* * * p<0.001 ; n=3$ repeats). Insu, insulin; Musc, muscimol; Rapa, rapamycin

in mice with diabetes induced by STZ neither protects against beta cell injury nor inhibits alpha cell proliferation [39]. In contrast, GABA treatment of mice with STZ-induced diabetes not only reduced ALDH1a3-positive and cKit-positive cells and preserved the insulin-positive-cell population, but also prevented the increase in alpha cell mass and hyperglucagonaemia. Moreover, GABA treatment prevented STZ-induced alpha cell proliferation in isolated islets. Together, these results suggest that increased alpha cell proliferation after beta cell injury possibly results from a decline in intraislet GABA signalling.

The number and mass of alpha cells expand in the first 2 3 weeks after STZ injection and then progressively decline [4, 39]. This phenomenon may be related to spontaneous alpha to beta cell transdifferentiation [40], in which alpha cellproduced GLP-1 [41] plays a critical role [5, 42, 43]. Indeed, in STZ-injected mice, alpha cells expressed high levels of GLP-1, and insulin immunoreactivity was identified in some Ki67-positive-cells. Moreover, beta cell mass became larger 2 weeks after STZ injection. These data support the notion that alpha to beta cell transdifferentiation may occur after severe beta cell injury [40].

Activation of $\mathrm{GABA}_{\mathbf{A}} \mathrm{R}$ signalling restrains alpha cell proliferation in vitro We also examined whether GABA restrained the proliferation of $\alpha \mathrm{TC} 1-6$ cells, a widely used mouse pancreatic alpha cell line $[44,45]$. We reason that if an increased number of alpha cells in type 1 diabetes results essentially from a decline in GABA and insulin, a GABA ${ }_{A} R$ 
Fig. 8 Proposed mechanism by which paracrine GABA and insulin regulate alpha cell proliferation. Under normal conditions, insulin, via insulin receptors (IRs) in alpha cells, activates the PI3K-Akt signalling pathway, maintaining plasma membrane expression of $\mathrm{GABA}_{\mathrm{A}}$ Rs. GABA, via $\mathrm{GABA}_{\mathrm{A}} \mathrm{Rs}$, induces membrane hyperpolarisation and limits $\mathrm{Ca}^{2+}$ entry via voltage-gated $\mathrm{Ca}^{2+}$ channels (VGCCs), hence lowering mTOR activity and restraining alpha cell proliferation. In recent-onset type 1 diabetes, the loss of functional beta cells results in a shortfall of GABA and insulin in the islets, and thus an immense increase in alpha cell proliferation
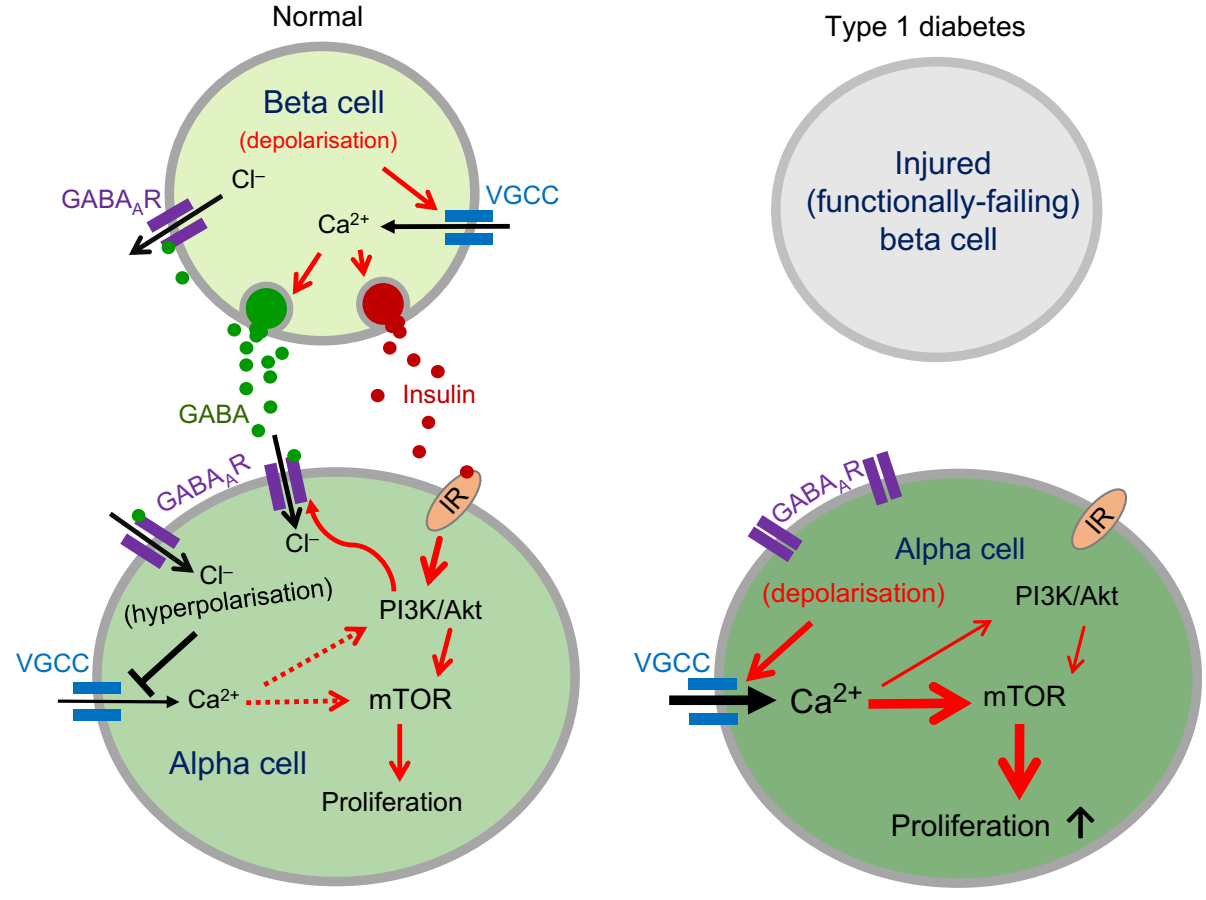

agonist and insulin should decrease $\alpha \mathrm{TC} 1-6$ cell proliferation. Our assays showed that the $\mathrm{GABA}_{\mathrm{A}} \mathrm{R}$ agonist muscimol alone had no effect on $\alpha \mathrm{TC} 1-6$ cell proliferation, whereas insulin significantly increased the cell proliferation as previously reported [7]. Remarkably, muscimol largely prevented the enhancing effect of insulin. Given that insulin increases $\mathrm{GABA}_{\mathrm{A}} \mathrm{Rs}$ on the surface of $\alpha \mathrm{TC} 1-6$ cells [12], we propose that insulin signals maintain $\mathrm{GABA}_{\mathrm{A}} \mathrm{Rs}$ on the surface of alpha cell and GABA, via $G_{A B A}$ Rs, retains alpha cell proliferation.

The $\mathrm{Ca}^{2+}$-dependent activity $[25,46]$ of mTOR upregulates the proliferation and renewal of pancreatic endocrine cells $[7$, 26]. Our assays showed that insulin increased the levels of p-mTOR and p-P70S6K in $\alpha$ TC1-6 cells, which was significantly prevented by muscimol. Of note, treating $\alpha \mathrm{TC} 1-6$ cells with insulin and muscimol did not affect p53 expression, suggesting that insulin stimulates alpha cell proliferation by activating a specific mTOR signalling cascade independent of p53 activity. Stimulating $\mathrm{GABA}_{\mathrm{A}} \mathrm{Rs}$ hyperpolarises alpha cells [12] and hence decreases voltage-gated $\mathrm{Ca}^{2+}$ channel activity [47]. Indeed, $\mathrm{Ca}^{2+}$-imaging analyses show that GABA significantly lowered cytosolic $\mathrm{Ca}^{2+}$. These combined data suggest that activating $\mathrm{GABA}_{\mathrm{A}} \mathrm{Rs}$ reduces $\mathrm{Ca}^{2+}$ entry and lowers mTOR activity.

As illustrated in Fig. 8, we propose that, in normal pancreatic islets, insulin signalling maintains a stable expression of $\mathrm{GABA}_{\mathrm{A}} \mathrm{Rs}$ on the surface of alpha cells, whereas GABA, through $\mathrm{GABA}_{\mathrm{A}} \mathrm{Rs}$, keeps the cells hyperpolarised, hence restraining their cytosolic $\mathrm{Ca}^{2+}$, mTOR activity and proliferation. Under conditions of type 1 diabetes, however, severe beta cell injury results in a decline in intraislet insulin and GABA, causing increased alpha cell proliferation. Thus, GABA treatment in rodents with STZ-induced diabetes facilitates beta cell generation [14, 15, 48], improves glucose tolerance [14] and prevents alpha cell proliferation. Severe beta cell injury may also induce alpha to beta cell transdifferentiation [40]. In this regard, two recent studies have demonstrated that long-term stimulation of $\mathrm{GABA}_{\mathrm{A}}$ Rs facilitates alpha to beta cell transdifferentiation $[49,50]$. However, whether GABA signalling regulates alpha to beta cell transdifferentiation after beta cell injury remains to be investigated in future studies.

Data availability The datasets generated during and/or analysed during the current study are available from the corresponding author on reasonable request.

Funding This research was supported by a Canadian Institutes of Health Research operating grant (MOP-133504) to WYL. The funder had no role in study design, data collection and analysis, decision to publish or preparation of the manuscript.

Duality of interest The authors declare that there is no duality of interest associated with this manuscript.

Contribution statement ALF, YYX, LG and GK made substantial contributions to conception and design, acquisition of data and drafting the article critically. QF contributed to interpretation of the results and revisions of the manuscript. WYL contributed to study design, data analysis, interpretation of the results and drafting and revisions of the manuscript. All authors approved the final version of the manuscript. WYL is responsible for the integrity of the work as a whole. 


\section{References}

1. Atkinson MA, Maclaren NK (1994) The pathogenesis of insulindependent diabetes mellitus. N Engl J Med 331:1428-1436

2. Cnop M, Welsh N, Jonas JC, Jorns A, Lenzen S, Eizirik DL (2005) Mechanisms of pancreatic beta-cell death in type 1 and type 2 diabetes: many differences, few similarities. Diabetes 54(Suppl 2): S97-S107

3. Willcox A, Richardson SJ, Bone AJ, Foulis AK, Morgan NG (2010) Evidence of increased islet cell proliferation in patients with recent-onset type 1 diabetes. Diabetologia 53:2020-2028

4. Li Z, Karlsson FA, Sandler S (2000) Islet loss and alpha cell expansion in type 1 diabetes induced by multiple low-dose streptozotocin administration in mice. J Endocrinol 165:93-99

5. Thyssen S, Arany E, Hill DJ (2006) Ontogeny of regeneration of beta-cells in the neonatal rat after treatment with streptozotocin. Endocrinology 147:2346-2356

6. Zhang Y, Zhang Y, Bone RN et al (2012) Regeneration of pancreatic non-beta endocrine cells in adult mice following a single diabetes-inducing dose of streptozotocin. PLoS One 7:e36675

7. Liu Z, Kim W, Chen Z et al (2011) Insulin and glucagon regulate pancreatic alpha-cell proliferation. PLoS One 6:e16096

8. Habener JF, Stanojevic V (2013) Alpha cells come of age. Trends Endocrinol Metab 24:153-163

9. Okada Y, Taniguchi H, Schimada C (1976) High concentration of GABA and high glutamate decarboxylase activity in rat pancreatic islets and human insulinoma. Science 194:620-622

10. Gerber JC 3rd, Hare TA (1979) Gamma-aminobutyric acid in peripheral tissue, with emphasis on the endocrine pancreas: presence in two species and reduction by streptozotocin. Diabetes 28:10731076

11. Reetz A, Solimena M, Matteoli M, Folli F, Takei K, De Camilli P (1991) GABA and pancreatic beta-cells: colocalization of glutamic acid decarboxylase (GAD) and GABA with synaptic-like microvesicles suggests their role in GABA storage and secretion. EMBO J 10:1275-1284

12. Xu E, Kumar M, Zhang Y et al (2006) Intra-islet insulin suppresses glucagon release via GABA-GABAA receptor system. Cell Metab 3:47-58

13. Braun M, Ramracheya R, Bengtsson M et al (2010) Gammaaminobutyric acid (GABA) is an autocrine excitatory transmitter in human pancreatic beta-cells. Diabetes 59:1694-1701

14. Soltani N, Qiu H, Aleksic M et al (2011) GABA exerts protective and regenerative effects on islet beta cells and reverses diabetes. Proc Natl Acad Sci U S A 108:11692-11697

15. Tian J, Dang H, Chen Z et al (2013) $\gamma$-aminobutyric acid regulates both the survival and replication of human beta-cells. Diabetes 62: 3760-3765

16. Best L (2005) Glucose-induced electrical activity in rat pancreatic beta-cells: dependence on intracellular chloride concentration. J Physiol 568:137-144

17. Davies SL, Roussa E, Le Rouzic P et al (2004) Expression of K+ $-\mathrm{Cl}^{-}$cotransporters in the alpha-cells of rat endocrine pancreas. Biochim Biophys Acta 1667:7-14

18. Dong H, Kumar M, Zhang Y et al (2006) Gamma-aminobutyric acid up- and downregulates insulin secretion from beta cells in concert with changes in glucose concentration. Diabetologia 49: 697-705

19. Bansal P, Wang S, Liu S, Xiang YY, Lu WY, Wang Q (2011) GABA coordinates with insulin in regulating secretory function in pancreatic INS-1 beta-cells. PLoS One 6:e26225

20. Feng MM, Xiang YY, Wang S, Lu WY (2013) An autocrine gamma-aminobutyric acid signaling system exists in pancreatic beta-cell progenitors of fetal and postnatal mice. Int J Physiol Pathophysiol Pharmacol 5:91-101
21. Rorsman P, Berggren PO, Bokvist K et al (1989) Glucose-inhibition of glucagon secretion involves activation of GABAA-receptor chloride channels. Nature 341:233-236

22. Andang M, Hjerling-Leffler J, Moliner A et al (2008) Histone $\mathrm{H} 2 \mathrm{AX}$-dependent GABA(a) receptor regulation of stem cell proliferation. Nature 451:460-464

23. Tozuka Y, Fukuda S, Namba T, Seki T, Hisatsune T (2005) GABAergic excitation promotes neuronal differentiation in adult hippocampal progenitor cells. Neuron 47:803-815

24. Kim JY, Liu CY, Zhang F et al (2012) Interplay between DISC1 and GABA signaling regulates neurogenesis in mice and risk for schizophrenia. Cell 148:1051-1064

25. Kwon G, Marshall CA, Pappan KL, Remedi MS, McDaniel ML (2004) Signaling elements involved in the metabolic regulation of mTOR by nutrients, incretins, and growth factors in islets. Diabetes 53(Suppl 3):S225-S232

26. Balcazar N, Sathyamurthy A, Elghazi L et al (2009) mTORC1 activation regulates beta-cell mass and proliferation by modulation of cyclin D2 synthesis and stability. J Biol Chem 284:7832-7842

27. Dong H, Xiang YY, Farchi N et al (2004) Excessive expression of acetylcholinesterase impairs glutamatergic synaptogenesis in hippocampal neurons. J Neurosci 24:8950-8960

28. Xiang FL, Lu X, Strutt B, Hill DJ, Feng Q (2010) NOX2 deficiency protects against streptozotocin-induced beta-cell destruction and development of diabetes in mice. Diabetes 59:2603-2611

29. Li Q, Lau A, Morris TJ, Guo L, Fordyce CB, Stanley EF (2004) A syntaxin 1 , Galpha(o), and N-type calcium channel complex at a presynaptic nerve terminal: analysis by quantitative immunocolocalization. J Neurosci 24:4070-4081

30. Powers AC, Efrat S, Mojsov S, Spector D, Habener JF, Hanahan D (1990) Proglucagon processing similar to normal islets in pancreatic alpha-like cell line derived from transgenic mouse tumor. Diabetes 39:406-414

31. Xiang YY, Dong H, Wan Y et al (2006) Versican G3 domain regulates neurite growth and synaptic transmission of hippocampal neurons by activation of epidermal growth factor receptor. J Biol Chem 281:19358-19368

32. Xiang YY, Chen X, Li J et al (2013) Isoflurane regulates atypical type-a gamma-aminobutyric acid receptors in alveolar type II epithelial cells. Anesthesiology 118:1065-1075

33. Burger DE, Lu X, Lei M et al (2009) Neuronal nitric oxide synthase protects against myocardial infarction-induced ventricular arrhythmia and mortality in mice. Circulation 120:1345-1354

34. Scholzen T, Gerdes J (2000) The Ki-67 protein: from the known and the unknown. J Cell Physiol 182:311-322

35. Tiemann K, Panienka R, Kloppel G (2007) Expression of transcription factors and precursor cell markers during regeneration of beta cells in pancreata of rats treated with streptozotocin. Virchows Arch 450:261-266

36. Magenta A, Avitabile D, Pompilio G, Capogrossi MC (2013) C-kitpositive cardiac progenitor cells: the heart of stemness. Circ Res 112:1202-1204

37. Kim-Muller JY, Fan J, Kim YJ et al (2016) Aldehyde dehydrogenase $1 \mathrm{a} 3$ defines a subset of failing pancreatic beta cells in diabetic mice. Nat Commun 7:12631

38. Pajvani UB, Accili D (2015) The new biology of diabetes. Diabetologia 58:2459-2468

39. Meier JJ, Ueberberg S, Korbas S, Schneider S (2011) Diminished glucagon suppression after beta-cell reduction is due to impaired alpha-cell function rather than an expansion of alpha-cell mass. Am J Physiol Endocrinol Metab 300:E717-E723

40. Thorel F, Nepote V, Avril I et al (2010) Conversion of adult pancreatic alpha-cells to beta-cells after extreme beta-cell loss. Nature 464:1149-1154 
41. Farilla L, Hui H, Bertolotto C et al (2002) Glucagon-like peptide-1 promotes islet cell growth and inhibits apoptosis in Zucker diabetic rats. Endocrinology 143:4397-4408

42. Kilimnik G, Kim A, Steiner DF, Friedman TC, Hara M (2010) Intraislet production of GLP-1 by activation of prohormone convertase $1 / 3$ in pancreatic alpha-cells in mouse models of sscell regeneration. Islets 2:149-155

43. Donath MY, Burcelin R (2013) GLP-1 effects on islets: hormonal, neuronal, or paracrine? Diabetes Care 36(Suppl 2):S145-S148

44. Wang J, Webb G, Cao Y, Steiner DF (2003) Contrasting patterns of expression of transcription factors in pancreatic alpha and beta cells. Proc Natl Acad Sci U S A 100:12660-12665

45. Watada H, Kajimoto Y, Miyagawa J et al (1996) PDX-1 induces insulin and glucokinase gene expressions in alphaTC 1 clone 6 cells in the presence of betacellulin. Diabetes 45:1826-1831
46. Laplante M, Sabatini DM (2012) mTOR signaling in growth control and disease. Cell 149:274-293

47. Drews G, Krippeit-Drews P, Dufer M (2010) Electrophysiology of islet cells. Adv Exp Med Biol 654:115-163

48. Purwana I, Zheng J, Li X et al (2014) GABA promotes human betacell proliferation and modulates glucose homeostasis. Diabetes 63 : 4197-4205

49. Li J, Casteels T, Frogne T et al (2017) Artemisinins target GABAA receptor signaling and impair alpha cell identity. Cell 168:86-100 e115

50. Ben-Othman N, Vieira A, Courtney M et al (2017) Long-term GABA administration induces alpha cell-mediated beta-like cell neogenesis. Cell 168:73-85 e11 